\title{
UNUSUAL PROPERTIES OF HYALURONATEPROTEIN ISOLATED FROM PATHOLOGICAL SYNOVIAL FLUIDS *
}

\author{
By DAVID HAMERMAN AND JOHN SANDSON $\dagger$
}

(From the Department of Medicine, Albert Einstein College of Medicine, and the Bronx Municipal Hospital Center, New York, N.Y.)

(Submitted for publication April 12, 1963 ; accepted August 13, 1963)

In joints actively involved by rheumatoid arthritis, the nature of the synovial fluid is quite different from normal. The fluid is increased in volume (10 to $30 \mathrm{ml}$ ) and contains large numbers of leukocytes $\left(>10,000\right.$ per $\left.\mathrm{mm}^{3}\right)$. The concentration of protein ( 4 to $5 \mathrm{~g}$ per $100 \mathrm{ml}$ ) is more than twice that of normal synovial fluid, whereas the concentration of hyaluronate $(0.1 \mathrm{~g}$ per 100 $\mathrm{ml}$ ) is reduced to one-third to one-half normal. Many studies have been made of the physical properties of rheumatoid synovial fluid (1), and although these reflect the physical state of the hyaluronate in the fluid, the hyaluronate has not been isolated for study.

Recently, mild methods were described to isolate hyaluronate from normal synovial fluids (2). Hyaluronate containing about $2 \%$ protein was obtained, and this product was called hyaluronateprotein (HP). Similar methods were used to isolate hyaluronate from rheumatoid synovial fluids, and a number of unusual findings were observed. A compound of hyaluronate combined with more protein (about 10\%) was isolated from the majority of the fluids; some of these products formed gels during dialysis in acetate buffer at $\mathrm{pH} 4.5$, and all showed immobilization at the origin during zone electrophoresis at $\mathrm{pH}$ 4.5. None of these properties of the hyaluronate in rheumatoid synovial fluids has been previously described. During the course of these studies, the question arose whether such findings were specific for HP from rheumatoid fluids. It appears that they are not, for in a preliminary study of fluids from a few

* Supported by graduate training grant $2 \mathrm{~A}-5082, \mathrm{Na}-$ tional Institute of Arthritis and Metabolic Diseases, and by grants from the U. S. Public Health Service (AM04804) and New York State Chapter Arthritis and Rheumatism Foundation. Presented in part before the Interim Session, American Rheumatism Association, December 1961.

† Investigator, Health Research Council of the City of New York (contract no. 1-157). patients with other joint diseases, HP with similar chemical analyses and physical properties was isolated from the synovial fluids of patients with chronic gout.

\section{SUBJECTS AND METHODS}

All 14 patients with rheumatoid arthritis had three well established criteria for this diagnosis: 1) chronic progressive, or recurrent, acute involvement of multiple peripheral joints with disability; 2) intermittent or persistent elevation of acute phase reactants; 3) X-ray evidence of knee joint disease showing, in mild cases, evidence of synovitis with effusion, and in severe cases, erosions of bone, cartilage loss, and ankylosis. Eight of the 14 patients had positive latex agglutination tests, three had subcutaneous nodules, and three had biopsies of the synovial membrane that showed changes compatible with rheumatoid arthritis.

The three patients with chronic gout had elevated serum uric acid levels, tophi, and X-ray evidence of lytic lesions in the bones.

Of the three other patients studied, one had chondromalacia patellae with joint effusion, one a menisceal tear with a bloody synovial effusion, and one a septic knee joint.

Isolation of hyaluronate. Synovial fluids were aspirated from the knee joints of patients. The isolation of hyaluronate from the fluid was usually started the same day, but not later than 48 hours after aspiration. All the fluids studied had a total protein concentration exceeding that of normal synovial fluid $[>25$ mg per $\mathbf{g}(1)]$.

The methods used to isolate hyaluronate are described in detail elsewhere (2). About 10 to $40 \mathrm{~g}$ of fluid from individual joints was diluted $1: 4$ with a buffer $(0.04 \mathrm{M}$ phosphate, $0.1 \mathrm{M} \mathrm{NaCl}, \mathrm{pH} \mathrm{7.2)}$ and dialyzed at $5^{\circ} \mathrm{C}$ for 24 hours in $500 \mathrm{ml}$ of this buffer changed twice daily. The dialyzed, diluted fluid was passed through a column of hydroxylapatite and IRC-50 cation-exchange resin. The eluate was ultrafiltered through Millipore filters of $0.1-\mu$ pore diameter. Most of the hyaluronate was retained on the filter, and protein was progressively removed by additional ultrafiltrations and ultracentrifugations (to remove insoluble residue trapped on the Millipore filters).

Analytical methods. Hyaluronate was measured by analysis for hexuronic acid. In these pathological synovial fluids, it was necessary to reduce the protein content 
before such a determination could be made. A 0.5 -g sample of the synovial fluid was diluted $1: 4$ with the phosphate- $\mathrm{NaCl}$ buffer and then dialyzed at $5^{\circ} \mathrm{C}$ for 2 days in a high ionic strength buffer $\left(0.1 \mathrm{M} \mathrm{CH}_{3} \mathrm{COONa}\right.$, $0.4 \mathrm{M} \mathrm{NaCl}$, acetic acid, $\mathrm{pH} 4.8$ ) changed twice daily. Testicular hyaluronidase 1 (about 500 turbidity reducing $\mathrm{U})$ was added, and the fluid incubated for 3 days at $37^{\circ}$ C. The fluid was ultrafiltered through a collodion membrane, ${ }^{2}$ and the ultrafilterable hyaluronate fragments, free of protein, were quantitatively recovered and analyzed for hexuronic acid.

\section{RESULTS}

\section{Purification of hyaluronate}

Data on the ratio of protein to hyaluronate are shown in Table I. The high ratios in the pathological fluids reflect the increased concentration of plasma proteins and the reduced hyaluronate concentration compared to normal fluids. In addition, protein fractions of high molecular weight were present that did not gain entry into normal fluids (3). Passage of the fluids through a column of hydroxylapatite and IRC-50 resin adsorbed some protein, part of which was of high molecular weight, such as beta-2 macroglobulin, beta-lipoprotein, and alpha- 2 macroglobulin. The initial ultrafiltration through the $0.1-\mu$ Millipore filters markedly reduced the protein content of the hyaluronate (Table I), but at least three or four ultrafiltrations were required before ratios of protein to hyaluronate were obtained that were reasonably constant. A second passage through the column of adsorbents was usually not effective in removing additional contaminating protein.

\section{Recovery of hyaluronate}

Careful analysis of hyaluronate (measured as hexuronic acid) was carried out during each step of the isolation procedures. Recovery of hexuronic acid from the column of adsorbents exceeded $95 \%$; recovery after the first ultrafiltration was, in most cases, about $80 \%$, as compared with $95 \%$ after this step in normal fluids. Some of the hexuronic acid of the pathological fluids passed through the Millipore filters. When the filtrate was collected, concentrated to a small volume, and subjected to zone electrophoresis at $\mathrm{pH} 7.4$, a hexuronic acid-containing component with the

\footnotetext{
1 Wyeth Co., Philadelphia, Pa.

2 Schleicher and Schuell, Keene, N. H.
}

TABLE I

Progressive purification of hyaluronate during its isolation from synovial fluids

\begin{tabular}{lcccc}
\hline \hline & \multicolumn{3}{c}{ Ratio. mg protein/mg } \\
& hyaluronate \\
\cline { 2 - 5 } \multicolumn{1}{c}{ Procedure } & $\begin{array}{c}\text { Normal } \\
\text { Col. }\end{array}$ & \multicolumn{2}{c}{ Rheumatoid } \\
& $1-30-62$ & \multicolumn{2}{c}{ DiP. } & Ort. \\
\hline Diluted, dialyzed synovial fluid & 7.1 & 47 & 43 \\
Adsorption 1 & 5.6 & 28 & 22 \\
Ultrafiltration 1 & .045 & .83 & .69 \\
Ultrafiltration 2 & .020 & .37 & .18 \\
Ultrafiltration 3 & .018 & .32 & .094 \\
Adsorption 2 & .016 & .38 & .18 & .051 \\
Ultrafiltration 4 & .018 & .13 & .051 \\
Ultrafiltration 5 & & & & \\
\hline
\end{tabular}

same mobility as a hyaluronate standard was identified.

On all subsequent ultrafiltrations, hexuronic acid recovery exceeded $90 \%$.

\section{Nature of isolated hyaluronateprotein}

A stable compound of hyaluronate containing about $10 \%$ protein was isolated from nine of fourteen patients with rheumatoid arthritis and from two of three patients with gout (Table II).

A. Electrophoresis. The first point to establish was the firm combination of hyaluronate and protein. The products were labeled with $\mathrm{I}^{131}$ and then subjected to zone electrophoresis over a wide $\mathrm{pH}$ range (4.5 to 12.0 ). In this way, as demonstrated with HP from normal synovial fluids (2), the mobility of hyaluronate (measured as hexuronic acid) and protein (determined by radioactivity) could be compared.

Zone electrophoresis at $\mathrm{pH} 6.4,7.4,8.6$, and 10.6 showed that hexuronic acid and protein migrated toward the anode in the same zone, indicating their firm combination (Figure 1). At $\mathrm{pH}$ 12 dissociation of the product occurred, as was noted with normal HP; unlike the normal, however, hexuronic acid migrated toward the anode ahead of the protein.

When zone electrophoresis was carried out at $\mathrm{pH} 4.5$, an unexpected finding occurred: $\mathrm{HP}$ remained immobilized at the origin (Figure 1). This was never observed during many similar studies of normal HP, even at higher concentrations of hyaluronate. At first it was thought that cationic charges contributed by the additional 
TABLE II

Hyaluronateprotein (HP) isolated from pathological synovial effusions

\begin{tabular}{|c|c|c|c|c|c|c|}
\hline \multirow[b]{3}{*}{ Patient } & \multirow[b]{3}{*}{ Diagnosis } & \multicolumn{2}{|r|}{ HP } & \multirow{2}{*}{\multicolumn{2}{|c|}{ Serum* }} & \multirow{3}{*}{$\begin{array}{c}\text { Biopsy } \\
\text { synovial } \\
\text { membrane* }\end{array}$} \\
\hline & & \multirow{2}{*}{ Ratio } & \multirow{2}{*}{$\frac{\text { mg protein }}{\text { mg hyaluronate }}$} & & & \\
\hline & & & & Latex & Vric acid & \\
\hline San. & Rheumatoid arthritis & & .069 & - & & \\
\hline Sch. & & & .098 & + & & + \\
\hline Che. & & & .095 & - & & \\
\hline Haw. & & & .068 & - & & \\
\hline Cas. & & & .049 & + & & + \\
\hline Cas. & & & .099 & & & \\
\hline Kat. & & & .089 & - & & \\
\hline DiP. & & & .13 & + & & \\
\hline Ort. & & & .049 & + & & \\
\hline Ort. & & & .051 & & & \\
\hline Gre. & & & .085 & - & & + \\
\hline Schw. & Gout & & .14 & - & 10 & \\
\hline
\end{tabular}

$*+=$ positive $;-=$ negative.

protein might neutralize the anionic groups of hyaluronate, but the total amount of protein was still too low to do this. It was then found that after adding Vitamin $\mathrm{C}$ or cysteine, in final concentrations of $70 \mu \mathrm{g}$ per $\mathrm{ml}$ or $600 \mu \mathrm{g}$ per $\mathrm{ml}$, respectively, HP moved toward the anode. Elec- trophoretic mobility of $\mathrm{HP}$ at $\mathrm{pH} 4.5$ seemed to be associated with the reduction in its viscosity brought about by either Vitamin $\mathrm{C}$ or cysteine (2). The finding that hyaluronate and protein migrated together after such treatment is strong additional evidence for their firm combination.

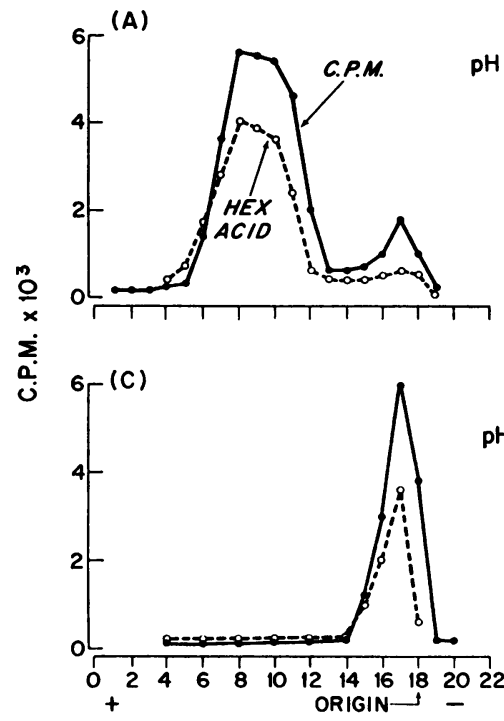

(B)

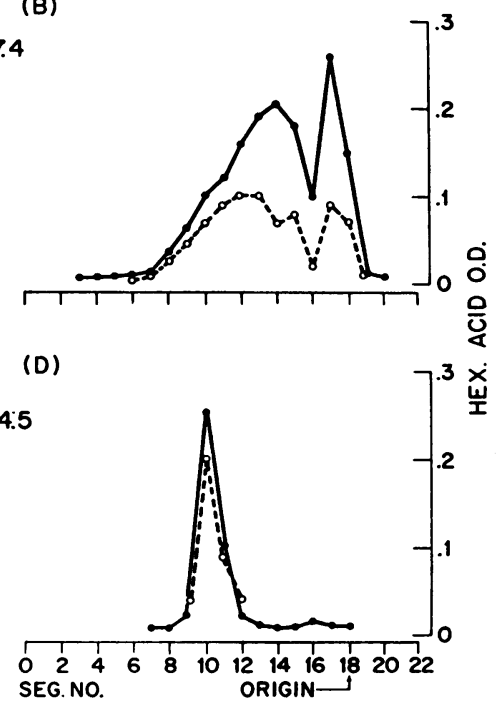

Fig. 1. Zone electrophoresis of hyaluronateprotein (HP) From RHeumatoid SYNovial fluids. Products were labeled with $\mathrm{I}^{12 x}$, and the migration of hyaluronate (hexuronic acid analyses) and protein ( ${ }^{181}$ determinations) were compared. At $\mathrm{pH} 7.4$, hyaluronate and protein migrated toward the anode as a single peak (A) or, as was observed with three products

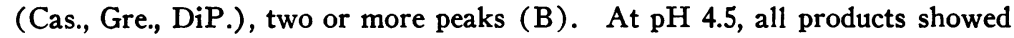
minimal migration or immobilization at the origin (C). At $\mathrm{pH} 4.5$, after addition of Vitamin $\mathrm{C}$, all products migrated toward the anode as a single peak (D). 
Two additional observations during zone electrophoresis at $\mathrm{pH} 4.5$ provide further evidence for combination of hyaluronate and protein. 1) If $\mathrm{HP}$ was first digested with streptococcal hyaluronidase to remove most of the hyaluronate from the protein, the protein remained at the origin during electrophoresis. Therefore, the migration of the protein with the hyaluronate, after Vitamin $\mathrm{C}$ or cysteine treatment, constitutes evidence for their firm combination in HP. 2) If $\mathrm{HP}$ was first digested with trypsin to remove most of the protein, hyaluronate migrated toward the anode. This shows that the integrity of the protein moiety is necessary for the electrophoretic immobility of $\mathrm{HP}$ at $\mathrm{pH} 4.5$.

The electrophoretic behavior of those products isolated from the synovial fluids obtained from the remainder of the patients with rheumatoid arthritis, from one patient with gout, and from the three patients with other joint diseases differed from that described for HP. After labeling with $\mathrm{I}^{131}$, zone electrophoresis at $\mathrm{pH} 4.5$ showed that the protein remained at the origin while hyaluronate migrated toward the anode. Additional evidence that in these products hyaluronate and protein were not firmly combined was observed during their isolation from synovial fluids; their protein content fell markedly with each additional ultrafiltration to levels below $2 \%$. It was not possible to explain why these products, in contrast to those designated HP, were not stable compounds. The condition of the isolated product could not be correlated either with the state of activity of the disease or with the treatment the patient received.

B. Viscosity. A most interesting finding was that three of six rheumatoid products tested and two products from the patients with gout formed gels during dialysis in acetate buffer $(\mathrm{pH} 4.5)$. These gels were placed in wide-bore Ostwald viscometers and failed to flow. No normal product of the many tested formed a gel after dialysis in the same buffer, even at higher concentrations of hyaluronate.

Formation of a gel occurred at hyaluronate concentrations greater than $0.1 \mathrm{~g}$ per $100 \mathrm{ml}$ during dialysis at $5^{\circ} \mathrm{C}$ in an acetate buffer, $0.075 \mathrm{M}, \mathrm{pH}$ 4.5. No gel formed when hyaluronate was dialyzed in acetate buffer, $0.075 \mathrm{M}, \mathrm{pH}$ 7.2. A gel that formed during dialysis in acetate buffer at $\mathrm{pH}$ 4.5 dissolved during dialysis in acetate buffer $\mathrm{pH}$

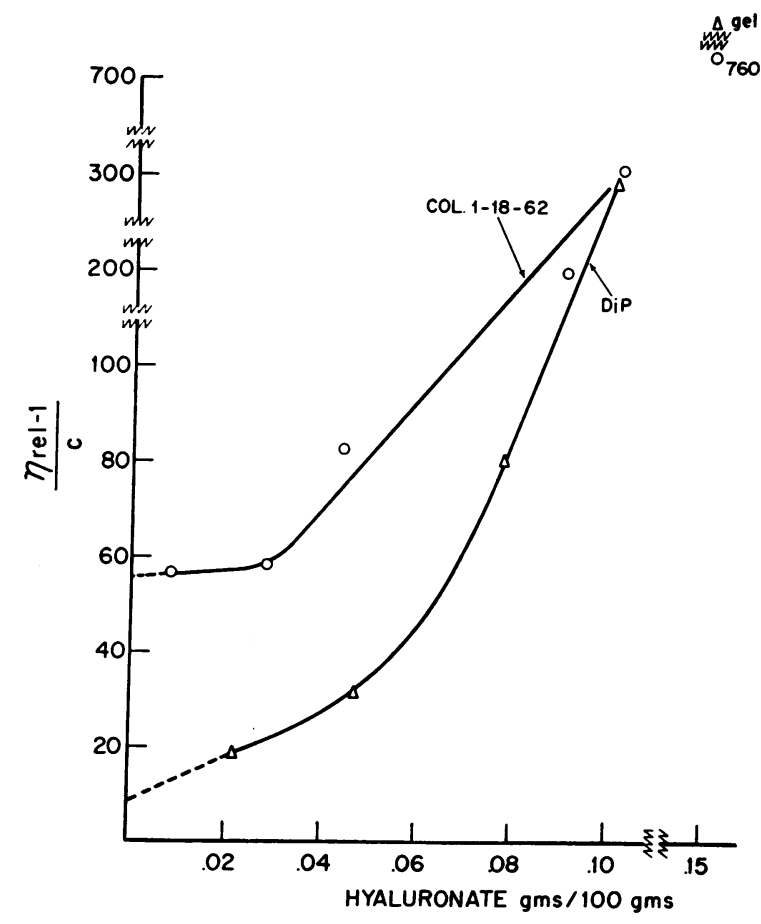

Fig. 2. Plot of the reduced viscosity vs. ConcenTRATION OF HYALURONATE OF NORMAL HP (COL. 1-18$62, \mathrm{O})$ OR RHEUMATOID HP (DiP., $\triangle$ ). Both products were dialyzed in an acetatae buffer $(0.075 \mathrm{M}, \mathrm{pH} 4.5)$. At a hyaluronate concentration of $0.15 \mathrm{~g}$ per $100 \mathrm{ml}$, the rheumatoid product was present as a gel and did not flow; the viscosity of the normal product was readily measurable although extremely high. Upon slight dilution (hyaluronate, $0.1 \mathrm{~g}$ per $100 \mathrm{ml}$ ), the gel was transformed to a free-flowing sol, and its viscosity and that of the normal product were similar; but with further dilution the viscosity of the rheumatoid product fell sharply and progressively to very low values. Similar findings were observed in a study of HP from a patient with gout (Whe.).

7.2 and formed once again during dialysis at $\mathrm{pH}$ 4.5. Formation of a gel occurred in the $\mathrm{pH} 4.5$ buffer in the presence of added urea $(6 \mathrm{M})$ or $\mathrm{NaCl}(0.3 \mathrm{M})$, suggesting that neither hydrogen bonding nor purely electrostatic interaction could account for gel formation.

Prior digestion of HP with trypsin prevented subsequent gel formation. This finding indicated the need for the intact protein in gelation. Addition of hyaluronidase or Vitamin $\mathrm{C}$ to $\mathrm{HP}$ also prevented gel formation. This showed that the protein moiety alone did not gel and that high molecular weight hyaluronate was required for gelation. The need for both the intact hyaluronate 


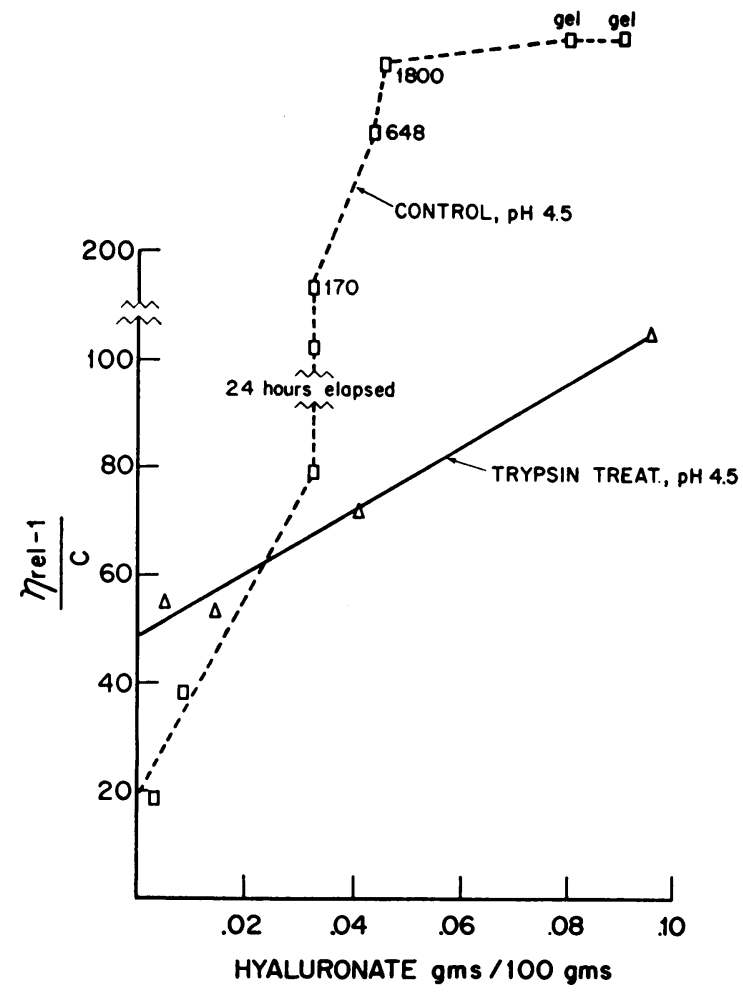

Fig. 3. Plot of the Reduced viscosity vs. hyaluronate CONCENTRation of Rheumatoid HP (GRe.). Part of this product (control, $\square$ ) was dialyzed in an acetate buffer $(0.075 \mathrm{M}, \mathrm{pH} 4.5)$. The gel that formed persisted upon slight dilution with the buffer; upon further dilution, the gel transformed to a free-flowing sol, the viscosity of which fell progressively with dilution. After 24 hours, there was a further fall in viscosity at the same hyaluronate concentration. Extrapolation of the viscosity measurements to zero concentration of hyaluronate showed that the limiting viscosity number (about 18) was very low. In contrast, the other part of the product $(\triangle)$ was treated with trypsin at $\mathrm{pH} 7.4$ and then dialyzed in acetate buffer, $\mathrm{pH}$ 4.5. No gel formed. The viscosity remained high with dilution; the limiting viscosity number (about 48 ) was similar to normal products.

and protein in gel formation is further evidence for a compound.

Gel-sol transformation. Increasing additions of $\mathrm{pH} 4.5$ buffer to the gel caused its fairly abrupt transformation to a free-flowing sol whose viscosity was markedly reduced (Figure 2 ). Indeed, viscosity of the sol was much lower than the viscosity of that part of the same sample of HP which was prevented from forming a gel by prior trypsin digestion (Figure 3). Although the nature of the association of $\mathrm{HP}$ chains that leads to gel formation is not known, subsequent dilution results in rather drastic physical changes in HP, as judged by the extremely low limiting viscosity number of these sols.

The gel was also quite sensitive to mechanical agitation. When briskly shaken for a few seconds, a free-flowing sol formed, and the gel was not restored when the sol was allowed to stand quietly at $5^{\circ} \mathrm{C}$ overnight.

C. Ultracentrifugation. Normal $\mathrm{HP}$ at $\mathrm{pH} 7.2$ and 4.5 sedimented slowly as a single sharp peak (Figure 4). No other components were observed. The patterns of rheumatoid HP differed from the normal. At $\mathrm{pH} 4.5$ those products that formed gels sedimented rapidly and piled up at the bottom of the cell shortly after the instrument reached full speed (Figure 5). A small amount of an additional component was observed that sedimented more slowly and that was not part of the gel. When gel formation was prevented by prior trypsin digestion, ultracentrifugation showed, at $\mathrm{pH} 4.5$, a single, sharp, slow-moving peak (Figure 6). At $\mathrm{pH} 7.2$ rheumatoid HP sedimented slowly at about the same rate as normal HP, and no rapidly sedimenting component was observed. The rheumatoid products, however, showed the presence in

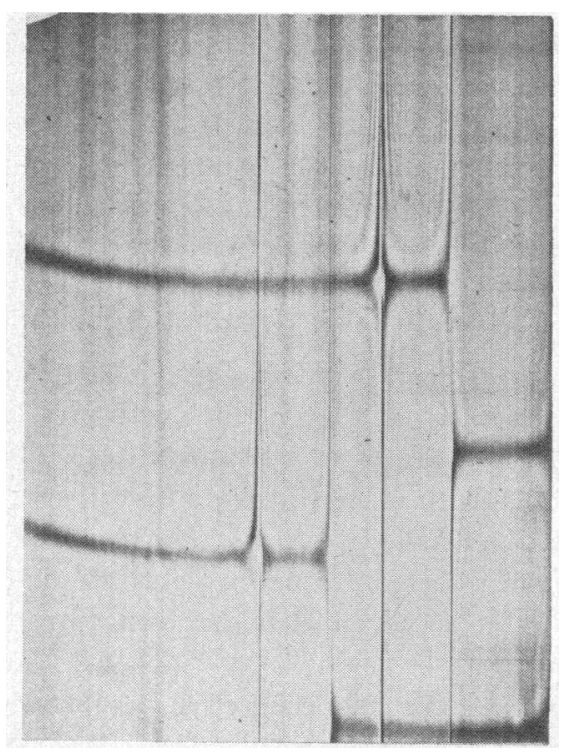

Fig. 4. Ultracentrifugation of normal HP (Col. 1-18-62) PREVIOUSLY DIALYZED IN ACETATE BUFFER, PH 7.2 (TOP) OR 4.5 (BOTTOM), 60 MINUTES AFTER REACHING FULL SPEED (59,780 RPM). A single sharp peak was observed at either $\mathrm{pH}$. Migration is from right to left in this and subsequent photographs. 
A

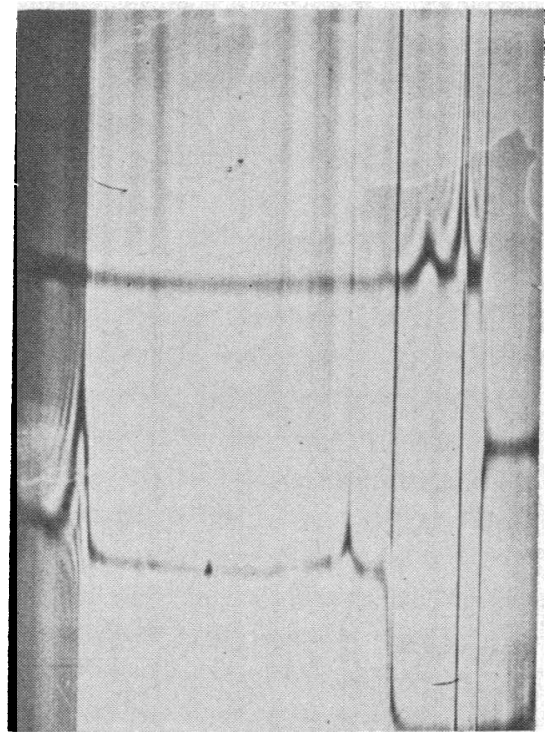

Fig. 5. Ultracentrifugation of Rheumatoid HP (DiP.) dialyzed in acetate BUFFER, PH 7.2 (TOP) OR 4.5 (BOTTOM) 15 MINUTES (A) AND 35 MINUTES (B) AFTER REACHING FULL SPEED. Note (in the bottom frames) that the gel that formed at $\mathrm{pH} 4.5$ sedimented rapidly to the bottom of the cell. A component present in small amount migrated more slowly. At $\mathrm{pH} 7.2$ (upper frames) HP sedimented slowly as a sharp peak. Immediately ahead an additional component was observed.

A
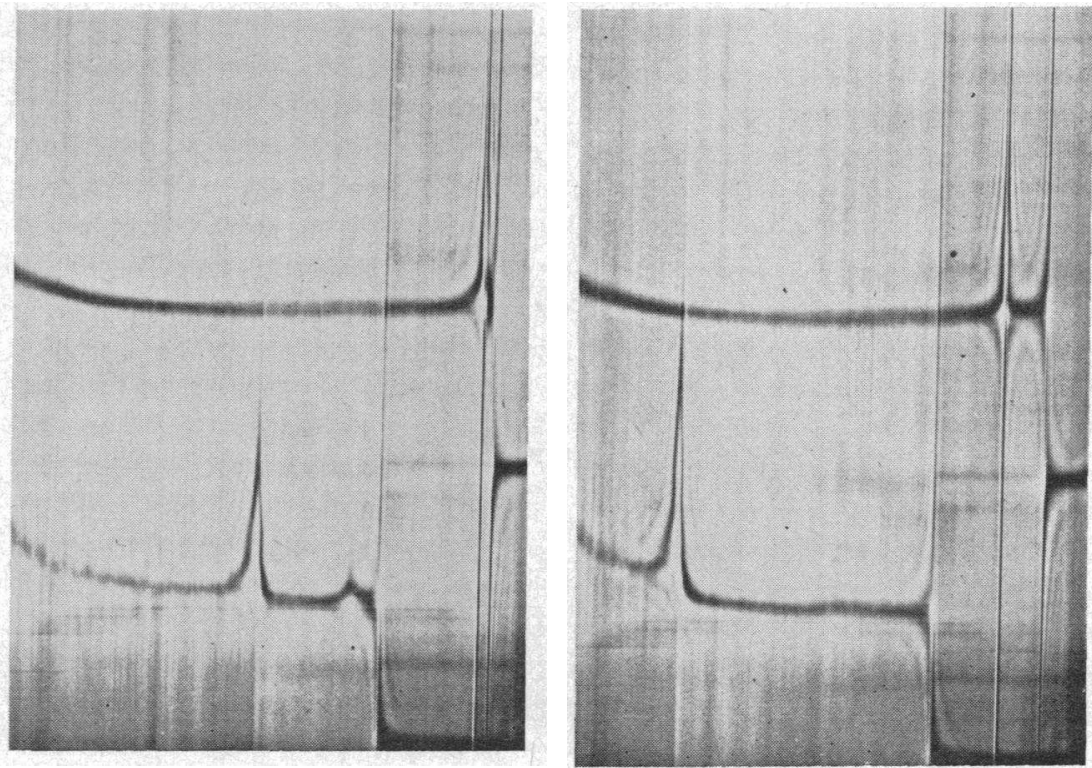

Fig. 6. Ultracentrifugation OF RHeUmatoid HP (Gre.) Dialyzed in aCETATE BUFFer, PH 4.5, 5 MINUTES (A) AND 30 MiNUTES (B) AFTER REACHING FULL SPEED. Part of the product was previously treated with trypsin to prevent gel formation, and sedimented slowly as a single sharp peak (upper frames). Part of the product not treated with trypsin formed a gel and sedimented rapidly (bottom frames). An additional component present in trace amounts migrated more slowly, and is seen in A. 


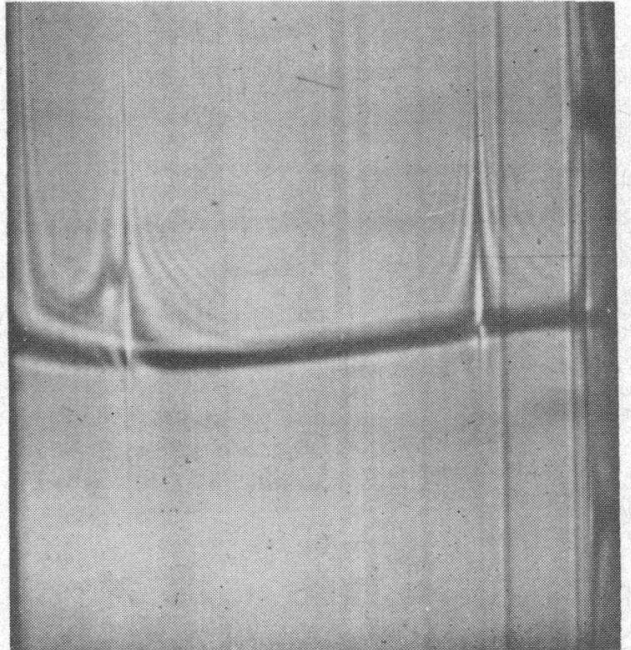

Fig. 7. Ultracentrifugation of HP dialyzed in ACETATE BUfFER, PH 7.2, FROM A PATIENT With GOUT (SCHW.) 64 minutes AFTER REACHING FULl SPEEd. The rapid sedimentation of most of this product suggested gel formation at neutral $\mathrm{pH}$. The remainder of the product sedimented slowly as a sharp peak. (This study was carried out with Dr. Edward Franklin).

trace amounts of a component that sedimented just ahead of the main peak (Figure 5). The identity of this component present in small amounts and visualized at 7.2 and 4.5 is not known.

A product from a patient with gout (Schw.) showed a particularly interesting finding (Figure 7 ). At $\mathrm{pH} 7.2$ a large part of this product sedimented rapidly toward the bottom of the cell, suggesting that some products can form gels at neutral $\mathrm{pH}$.

D. Attempts to reproduce the unusual properties of these products by adding proteins to normal synovial fluid. A rather critical point was to show that the unique chemical and physical properties of $\mathrm{HP}$ obtained from pathological fluids were not due to the presence of large amounts of plasma proteins and white cells in these fluids. To try to duplicate the conditions in pathological fluids, either serum or plasma from patients with active rheumatoid arthritis was added to samples of normal synovial fluid. The hyaluronate was isolated and found to contain about $2 \%$ protein. The isolated hyaluronate did not form a gel during dialysis in acetate buffer at $\mathrm{pH}$ 4.5 and moved toward the anode during zone electrophoresis at $\mathrm{pH}$ 4.5.
To test further the effects of inflammatory exudates on the properties of normal hyaluronate, an extract of frozen and thawed erythrocytes and leukocytes was added to a solution of normal HP. Ultrafiltration was then carried out twice. The isolated product contained about $3 \%$ protein. It migrated toward the anode during zone electrophoresis at $\mathrm{pH} 4.5$.

\section{DISCUSSION}

From synovial fluids obtained from patients with active rheumatoid arthritis or chronic gout, a compound of hyaluronate and protein ( $\mathrm{HP}$ ) has been isolated and its properties studied. HP contained about $10 \%$ protein, compared to $2 \%$ protein consistently found in $\mathrm{HP}$ from normal synovial fluids. Evidence that a compound of hyaluronate and protein has been obtained from pathological synovial fluids may be summarized as follows: 1) The ratio of protein to hyaluronate in HP remained reasonably constant after the fourth ultrafiltration. 2) When HP was labeled with $\mathrm{I}^{131}$, zone electrophoresis at $\mathrm{pH} 6.4,7.4,8.6$, and 10.2 showed migration of hyaluronate, measured as hexuronic acid, and protein, identified by radioactivity, toward the anode in the same zone, with less than $15 \%$ of the radioactivity remaining at the origin. 3) During zone electrophoresis at $\mathrm{pH}$ 4.5, HP remained immobilized at the origin. After treatment with Vitamin $\mathrm{C}$ or cysteine, which reduced the viscosity of $\mathrm{HP}$, hyaluronate and protein migrated together toward the anode. 4) Some of the products formed gels during dialysis in an acetate buffer, $\mathrm{pH}$ 4.5. Prior digestion of HP with either hyaluronidase or trypsin prevented gel formation. Both the intact hyaluronate and protein were needed for gel formation, which is additional evidence for a compound.

Neither the higher protein content nor the unusual physical properties HP showed at low $\mathrm{pH}$ could be reproduced when components of inflammatory synovial effusions (plasma proteins, leukocytes, and erythrocytes) were added to normal synovial fluids or to solutions of normal HP, and the hyaluronate isolated. The isolated hyaluronate contained about $2 \%$ protein, did not form a gel during dialysis in acetate buffer at $\mathrm{pH} 4.5$, and migrated toward the anode during zone electrophoresis at $\mathrm{pH} 4.5$. This inability to reproduce 
the unusual properties shown by $\mathrm{HP}$ from pathological fluids indicates that $\mathrm{HP}$ is not an artifact produced during isolation and that it exists in the native synovial fluid. Since hyaluronate is synthesized by cells in the synovial membrane (4), it is possible that cells in the pathological synovial membrane synthesize this unusual compound of hyaluronate and protein.

The higher protein content and some type of interaction of hyaluronate and this protein are responsible for the unique finding that a protein moiety can influence the physical properties of hyaluronate. The integrity of the protein moiety was shown to be necessary for gel formation and for immobility during zone electrophoresis at $\mathrm{pH}$ 4.5. These properties were not observed in normal HP, presumably because the protein moiety is such a small part of the compound (2).

Whether the gel can form in vivo is, of course, unknown. Cells of the synovial membrane in rheumatoid arthritis exhibit high glycolytic activity and produce increased amounts of lactate $(5,6)$, which might lower the $\mathrm{pH}$ locally. It is unlikely, however, that the $\mathrm{pH}$ can actually fall to levels low enough to induce gel formation of $\mathrm{HP}$ in the synovial membrane, and if the gel did form there, other factors would have to contribute as well. In this connection it has been postulated (7) that high glycolytic activity and increased lactate production in joint tissues from patients with gout can sufficiently lower the $\mathrm{pH}$ locally to cause further precipitations of urate crystals and continue the cycle of inflammation.

\section{SUM MARY}

1) A compound of hyaluronate and protein (HP) isolated from synovial effusions obtained from patients with rheumatoid arthritis or gout showed a number of unusual properties that distinguished it from normal HP.
2) The HP from pathological effusions contained more protein (about 10\%); remained immobilized at the origin during zone electrophoresis at $\mathrm{pH} 4.5$; and formed a gel during dialysis in an acetate buffer, $\mathrm{pH} 4.5$.

3) Evidence has been presented that the protein moiety can influence some physical properties of the hyaluronate. Trypsin digestion of $\mathrm{HP}$ led to migration of hyaluronate toward the anode during zone electrophoresis at $\mathrm{pH}$ 4.5. Digestion of $\mathrm{HP}$ with trypsin prevented gel formation.

4) To show that HP from pathological effusions was not an artifact of the isolation procedures, plasma proteins or leukocytes and erythrocytes were added to normal synovial fluids or to normal HP. The isolated, purified hyaluronate showed neither electrophoretic immobility nor gel formation at $\mathrm{pH} 4.5$.

\section{ACKNOWLEDGMENT}

The technical assistance of Miss Hilda Schuster and Mrs. Eleanor Weissenbach is gratefully acknowledged.

\section{REFERENCES}

1. Hamerman, D., and M. Schubert. Diarthrodial joints, an essay. Amer. J. Med. 1962, 33, 555.

2. Sandson, J., and D. Hamerman. Isolation of hyaluronateprotein from human synovial fluid. $J$. clin. Invest. 1962, 41, 1817.

3. Schur, P. H., and J. Sandson. Immunoelectrophoretic comparison of proteins of various molecular sizes in synovial fluid and serum (abstract). Arth. and Rheum. 1962, 5, 320.

4. Yielding, K. L., G. M. Tomkins, and J. J. Bunim. Synthesis of hyaluronic acid by human synovial tissue slices. Science 1957, 125, 1300.

5. Thomas, D. P. P., and J. T. Dingle. Studies on human synovial membrane in vitro. The metabolism of normal and rheumatoid synovia and the effect of hydrocortisone. Biochem. J. 1958, 68, 231.

6. Hamerman, D., and R. Wu. Unpublished observations.

7. Seegmiller, J. E., and R. R. Howell. The old and new concepts of acute gouty arthritis. Arth. and Rheum. 1962, 5, 616. 